\title{
Phenology, growth and biomass of Cystoseira balearica in Calvi (Corsica)
}

\author{
L. Hoffmann, R. Renard, V. Demoulin \\ University of Liège, Department of Botany B22, Sart Tilman, B-4000 Liège, Belgium
}

\begin{abstract}
Six plants of Cystoseira balearica Sauv. were examined in the field over a period of 4 yr in the Calvi area (northwestern coast of Corsica, France) in spring (March), summer (June) and autumn (October). On each occasion, branch and stem length was measured and presence of iridescence and conceptacles was observed. The phenology of the different plants and survivorship of individual branches of these plants were followed through tagging. It is shown that C. balearica has 2 growing periods, losing its branches twice a year (in late summer and in winter). An average plant produces $2.4 \mathrm{~g}$ $\mathrm{C} \mathrm{yr}^{-1}$; more than $90 \%$ of this biomass enters the ecosystem in the form of dead organic remains. This represented about $3.7 \mathrm{tC}$ for the whole population of $C$ balearıca in Revellata Bay near Calvi.
\end{abstract}

\section{INTRODUCTION}

Cystoseiracean algae inhabit rocky substrates in the intertidal and subtidal zones of many temperate and tropical regions (Nizamuddin 1970). This is especially the case in the Mediterranean Sea where the different species of Cystoseira form a productive belt which plays an important ecological role as shelter and food. In the Calvi area, on the northwest coast of Corsica, France, Cystoseira balearica used to be the dominant component of the macroalgal vegetation on rocky substrates in the infralittoral down to a depth of $30 \mathrm{~m}$ (Clarisse 1984). However, since 1987 a dramatic regression of these algae has been noticed (Hoffmann et al. 1988)

Several studies have examined the distribution, growth and morphology of Cystoseira spp. in the Mediterranean and Black Sea (Sauvageau 1912, Ercegovic 1952, Boudouresque 1969, Bavaru 1972, Knoepffler-Peguy 1973, Khailov 1978, 1979, Firsov \& Khailov 1979, Gomez Garreta et al. 1982). On the western coast of the United States, the demography of C. osmundacea stands was studied by Gunnill (1986) and Schiel (1985a). However, little is known about the phenology, biomass and productivity of individual plants of Cystoseira, especially of C. balearica, that is fundamental to nearshore food chains.

Questions such as when do plants grow, what sizes do they attain, and when do they reproduce, and a de- scription of their survivorship are relevant to an understanding of the distribution and abundance of species and hence to community structure. Yet it is only by continued observation on marked plants that seasonal periodicity in growth and reproduction can be established. We therefore designed a tagging program over 4 yr (1983 through 1986) to determine the growth, reproduction and survivorship of individual branches of the brown alga Cystoseira balearica near Calvi.

\section{STUDY SITE}

The study was conducted at STARESO, the oceanographic station of the University of Liège, Belgium, located in Revellata Bay on the west side of the Gulf of Calvi (northwestern Corsica). The coast is composed of carboniferous granites with very rugged cliffs. The bottom of the bay is occupied by sand colon:zed by seagrass meadows (mainly Posidonia oceanica). The annual pattern of surface temperatures presents a summer maximum in August (mean monthly temperature 1981 to $1990: 24.6^{\circ} \mathrm{C}$ ) and a winter minimum in February (mean monthly temperature 1981 to 1990: $13^{\circ} \mathrm{C}$ ). Strong winds mainly occur during winter. Further information about hydrology and physical and chemical properties of the gulf waters can be found in Bay (1984) and Frankignoulle (1986). 
Six plants of Cystoseira balearica were regularly surveyed at the 'crique Levy' near the STARESO marine station in Calvi. The 6 plants were on a plot of $1 \mathrm{~m}^{2}$ at a depth of $4 \mathrm{~m}$ and grew on the NE face of a rock with an inclination of 10 to $15 \%$. C. balearica was accompanied at this site by Padina pavonica, Acetabularia acetabulum, Dictyopteris membranacea, Dictyota dichotoma, Udotea petiolata, and Halopteris scoparia.

\section{MATERIALS AND METHODS}

From February 1983 until June 1986, plants were examined every spring (February or March), summer (June) and autumn (October). On these occasions, a lightweight numbered plastic tag $(10 \times 5 \mathrm{~mm})$ was attached with a plastic cable to every new stem and primary branch $\geq 2 \mathrm{~cm}$ in length. On each occasion a different tag colour was used. For each stem and primary branch, length was measured with a ruler. Numbering of individual branches permitted monitoring of the number and length of branches per stem and per plant, the appearance or disappearance of branches and stems, and the length-increment of individual branches and stems between 2 occasions. Furthermore, the presence of conceptacies and iridescence was noted.

To evaluate the standing crop, the length-weight relationship of branches and stems was assessed. At the end of the study, branches and stems of different length were weighed after removal of the epiphytes to obtain the fresh weight, then dried for $24 \mathrm{~h}$ at $105^{\circ} \mathrm{C}$ and reweighed for dry weight.

\section{RESULTS}

\section{Survivorship and phenology}

All 6 plants studied were still present and alive after the 40 mo investigation period. The mean life expectancy of stems was on average $12 \mathrm{mo} ; 30 \%$ of the stems lived up to $6 \mathrm{mo}, 32 \%$ up to $12 \mathrm{mo}$ and $38 \%$ survived longer than this age. Maximum age recorded for a stem was $33 \mathrm{mo}$. The largest renewal of stems took place during the winter-spring period. Thus an average of $35 \%$ of stems disappeared between October and March and during the same period $37.5 \%$ new stems appeared (Table 1). The disappearance of a high percentage of tagged stems during the winter was probably the consequence of strong winds and waves observed from December through January. It is impossible to say whether the newly tagged stems were really new stems or whether they were old stems that broke during the stormy winter period, thus losing
Table 1. Cystoseira balearica. Frequencies of 'old' stems and of stems lost at different periods of the year

\begin{tabular}{|lllrl|}
\hline \multicolumn{2}{c}{$\%$ of 'old' stems } & \multicolumn{2}{c}{$\%$ of stems lost during: } \\
\hline March & $62.5 \pm 11.4$ & March-June & $5.9 \pm 5.4$ \\
June & $91.2 \pm 2.8$ & June-October & $7.7 \pm 2.6$ \\
October & $90.1 \pm 6.4$ & October-March & $35.4 \pm 10.8$ \\
\hline
\end{tabular}

their plastic tag, and that started to grow again and were tagged again in March. Between March and June, as well as between June and October, less than $10 \%$ of the stems disappeared; during the same period, the rate of formation of new stems was also lowest (less than $10 \%$ ). Thus the stems are probably perennial structures.

The branches, by contrast, are seasonal structures. Cytoseira balearica plants reached their largest size during the summer months when they formed dense stands. In October all the primary branches present in June had disappeared and all the branches observed in autumn were new ones (Table 2). The same is true for the October to March period: only very few branches (less than $1 \%$ ) survived the winter and almost all branches observed in March were newly developed. The situation was different in June: only $27.9 \%$ of the branches present in March had disappeared in June. Within the branches present in June, $57 \%$ were already observed in March, whereas $43 \%$ were newly formed. The life expectancy of primary branches varies between 3 and 6 mo. The $C$. balearica plants in the surveyed plot thus lost their branches twice a year and had 2 distinct growth periods.

In March and June conceptacles were observed on 47 to $65 \%$ of the primary branches, with the exception of June 1985 when less than $1 \%$ bore reproductive structures (Fig. 1). In October, less than $15 \%$ of the branches showed conceptacles. In June when the plants were composed of 'old' branches (formed between October and March) and 'new' branches (formed between March and June), only a small proportion (less than $30 \%$ ) of the latter branches presented reproductive structures, whereas up to $92 \%$ (June 1986) of the 'old' branches showed the presence of conceptacles. Iridescence was generally associated with 'new', growing branches (Fig. 1). In March and

Table 2. Cystoseira balearica. Frequencies of 'old' branches and of branches lost at different periods of the year

\begin{tabular}{|lllc|}
\hline$\%$ of 'old' branches & \multicolumn{2}{c|}{$\%$ of branches lost during: } \\
\hline March & $<1$ & March-June & $27.9 \pm 2.7$ \\
June & $57 \pm 3.8$ & June-October & 100 \\
October & $<1$ & October-March & $>99$ \\
\hline
\end{tabular}


Fig. 1 Cystoseira balearica. Frequency of conceptacle-bearing 'old' (black bar) and 'new' lopen bar) branches in March, June and October No. above bar $=$ percentage of iridescent branches

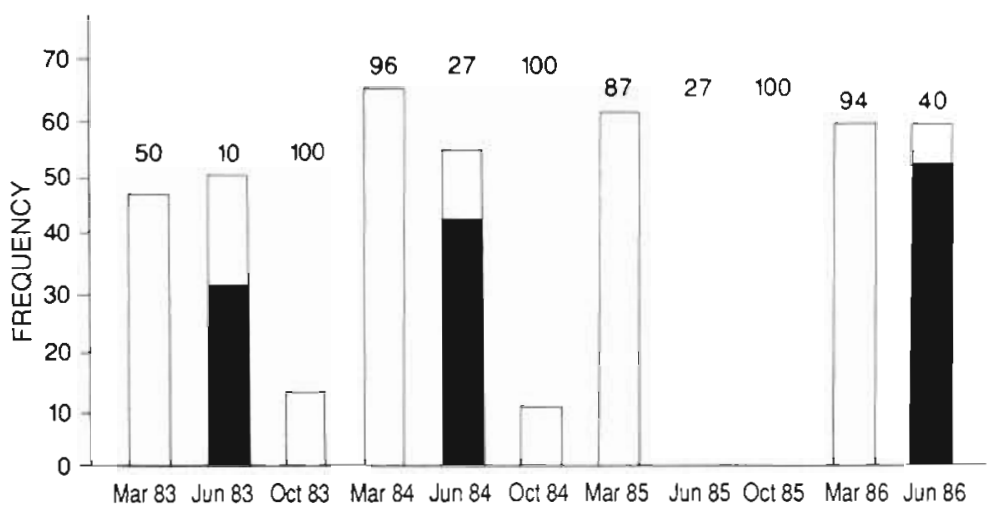

length varied between 2.2 and $3.7 \mathrm{~cm}$; the longest stem reached $13 \mathrm{~cm}$. Mean number of stems plant ${ }^{-1}$ varied little from one season to another (10.1 to 14.8) (Fig, 4). A slight increase was observed in 1985. The highest number of stems plant ${ }^{-1}$ observed was 20. The increase of biomass from March to October was mainly due to an increase in stem length and not in number. Calculated on the basis of results from 1984 and 1985 , stem biomass produced plant ${ }^{-1}$ and $\mathrm{yr}^{-1}$ represented an average of $0.68 \mathrm{~g}$ dry weight.

The standing crop of primary branches was highest in June, except for 1985 when the maximum was observed in March (Fig 5); the minimum biomass occurred in October. In March the mean biomass of branches plant ${ }^{-1}$ varied between 1.08 and $3.42 \mathrm{~g}$ dry weight, in June between 1.28 and $5.9 \mathrm{~g}$, and in October between 0.63 and $1.2 \mathrm{~g}$. Maximum biomass of branches observed plant ${ }^{-1}$ amounted to $7.2 \mathrm{~g}$ dry weight. As previously mentioned, almost all branches present in March and October had newly grown since the previous October and June respectively. The biomass observed is thus produced in the 3 preceding months. In June the biomass can be divided into 3 parts: the biomass already present in March, the biocentage of shorter new stems was also observed. Mean

The biomass of the stems was evaluated at $25.1 \mathrm{mg}$ dry weight (cm length) $)^{-1}$.

Total stem biomass increased from spring to autumn (Fig. 3); the mean for the 6 plants varied from 0.635 to $1.274 \mathrm{~g}$ of dry weight plant ${ }^{-1}$. The highest stem biomass recorded for 1 plant was $1.669 \mathrm{~g}$ dry weight. Between October and March stem biomass as well as stem length (Fig. 4) decreased. In March, a high per-

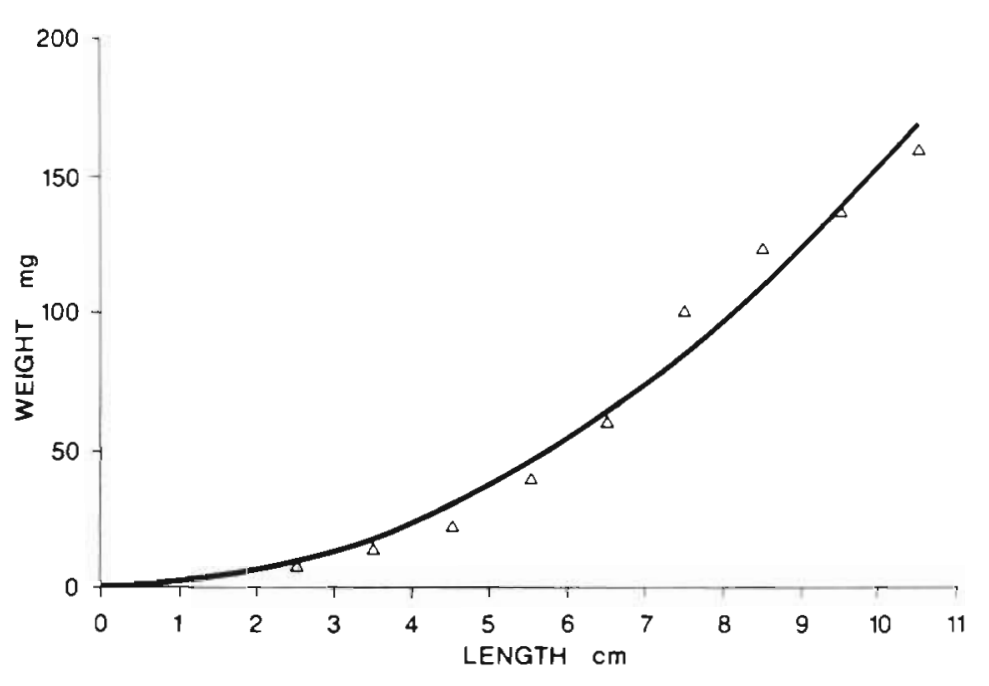

Fig. 2. Cystoseira balearica. Changes in dry weight of branches with increasing length 


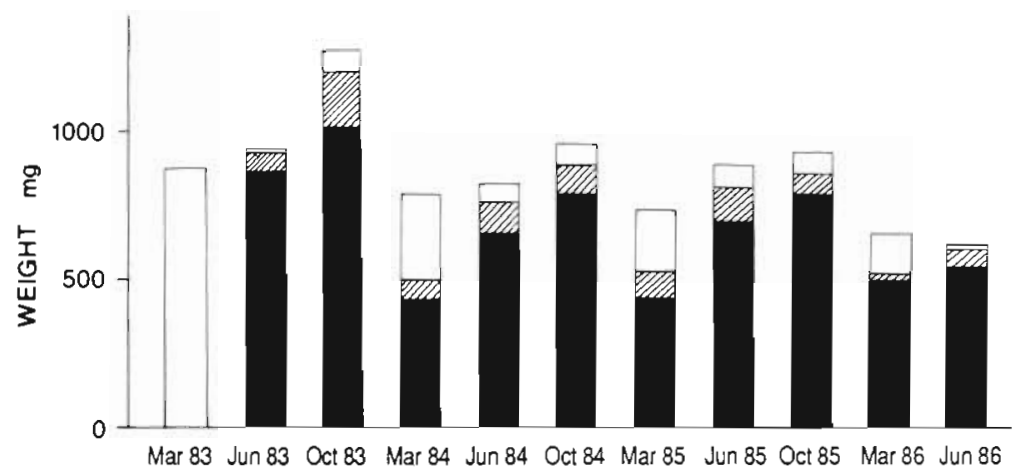

Fig. 3. Cystoseira balearica. Mean stem biomass (dry weight) plant ${ }^{-1}$ Black bar: biomass at previous campaign; hatched bar: biomass increase of these 'old' stems since previous campaign; open bar: biomass due to newly grown stems since previous campaign mass produced by branches already present in March. and the biomass produced by new branches. Mean biomass of branches produced plant ${ }^{-1}$ was $7.7 \mathrm{~g}$ in $1983,4.9 \mathrm{~g}$ in 1984 and $4.7 \mathrm{~g}$ in 1985. An important decrease is observed in the standing crop of Cystoseira balearica when the values of March or June are compared over the entire study period. From 1987 onwards the decline was so pronounced that growth measurements became meaningless (Demoulin unpubl.). It should be noted that this estimate is a minimal one because it reflects only the growth of whole primary branches while each living branch, as long as it stays on the stem, not only grows, but also sustains losses of its own structural elements (secondary branches), so that the biomass formed by it is in fact greater than the average mass of the branch. Furthermore, the plants did not necessarily present their maximum biomass during the measurements which took place in June and October.

Maximum number of primary branches and maximum total length were observed in June (Fig. 6). Mean number of branches plant ${ }^{-1}$ varied between 23.3 and 65.8 ; the maximum observed amounted to 68 branches. Mean total length of primary branches plant ${ }^{-1}$ varied between 1.2 and $4.5 \mathrm{~m}$; the maximum observed amounted to $5.4 \mathrm{~m}$ for 1 plant. Mean number of branches stem ${ }^{-1}$ varied between 1.9 and 3.4 except for June 1983 when 5.7 branches stem ${ }^{-1}$ were observed.

\section{DISCUSSION}

The most frequently occurring growth cycle within the genus Cystoseira seems to consist of 1 seasonal growth period, the development of reproductive fronds and the abrupt shedding of most of the thallus. Thus, most Mediterranean species lose their branches generally in autumn with the beginning of the cold season, only leaving the holdfasts with the perennial stems during a more or less long resting period in the winter (Sauvageau 1912). A similar growth cycle has been described for C. osmundacea (Turner) A. Ag. in California (Schiel 1985a) and also from several species of the related genus Sargassum, i.e. S. muticum (Yendo) Fensholt (Norton 1977, Aguilar-Rosas \& Machado Galindo 1990), S. sinclairii Hook. \& Harv. (Schiel 1985b) For C. balearica this growth cycle is described by Gomez Garreta et al. (1982) for plants growing on the island of Mallorca. In contrast to these findings, the plants of C. balearica included in our tagging program lost almost all (more than $99 \%$ ) their branches twice a year, i.e. during the late summer (between June and October) and during the winter (between October and March); the stems, on the contrary, are perennial structures.

Thus 2 distinct growth periods of new branches exist: the first type of branches appears during winter; in March these already reached a mean length of $7 \mathrm{~cm}$

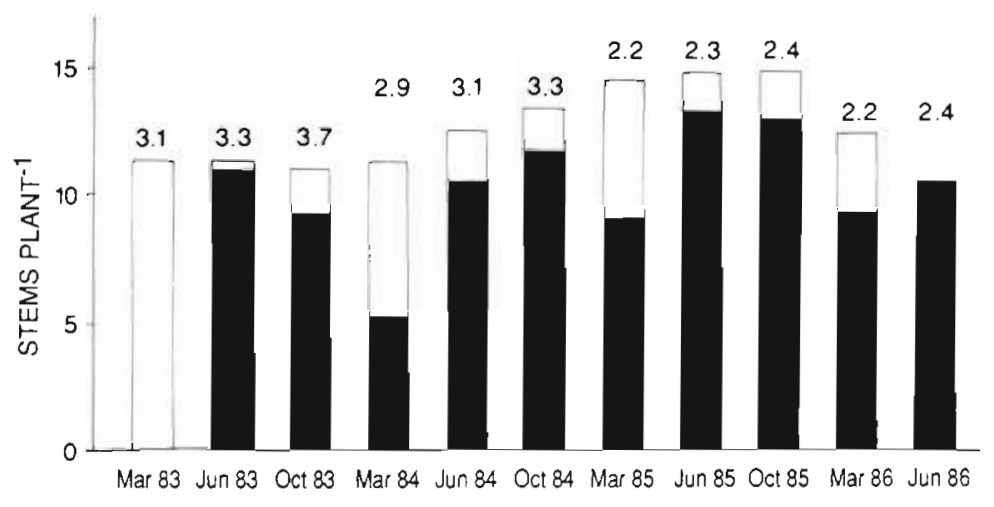

Fig. 4. Cystoseira balearica. Mean no. of stems plant $^{-1}$ over time (black bar: 'old' stems; open bar: 'new' stems). No. above bar = mean length (cm) of stems 
Fig. 5. Cystoseira balearica. Mean branch biomass (dry weight) plant ${ }^{-1}$ Black bar: biomass at previous campaign; hatched bar: biomass increase of these 'old' branches since previous campaign; open bar biomass due to newly grown branches since previous campaign

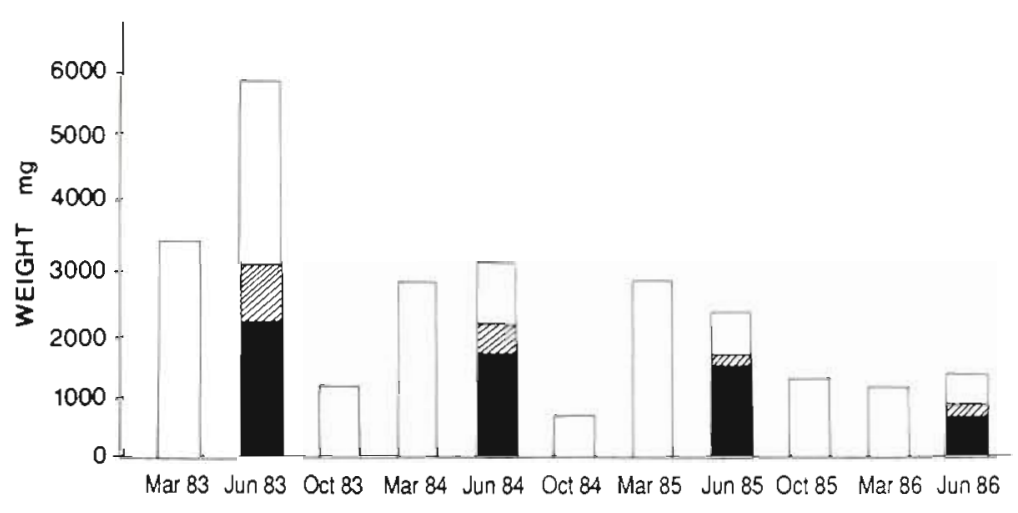

Branch and stem losses are very high compared to the total organic matter formed by the thallus; thus the perennial biomass of the plants only increased by $20 \mathrm{mg} \mathrm{yr}^{-1}$ due to new stems and the growth of the latter. The main growing season of Cystoseira balearica was the winter-spring period in which ca $70 \%$ of the total yearly biomass is produced.

Besides extensive sea grass meadows formed by Posidonia oceanica and Cymodocea nodosa and which cover more than $50 \%$ of the Revellata Bay, phytoplankton and benthic algae on the rocky coast are the basic compartments of primary producers around Calvi. Although these sea grass beds are very productive (Bay 1984), they do not seem to be of great importance as carbon suppliers to the marine food web. Dauby (1989) showed, indeed, by stable carbon isotope ratio analyses that the fraction of the diet of particle-feeding organisms originating from Posidonia is very low (mean $6 \%$ ) compared to the planktonic (mean $59 \%$ ) and the seaweed carbon (35\%). Mean yearly biomass production by $C$. balearica in this study amounts to $6.5 \mathrm{~g}$ plant ${ }^{-1} \mathrm{yr}^{-1}$ Considering a carbon content of $37 \%$ (Atkinson \& Smith 1983), this production corresponds to $2.4 \mathrm{~g} \mathrm{C}$ plant $^{-1} \mathrm{yr}^{-1}$. If we admit an average of 20 plants $\mathrm{m}^{-2}$, an estimated $130 \mathrm{~g}$ dry weight $\mathrm{m}^{-2}$ is produced per year $\left(=48.1 \mathrm{~g} \mathrm{C} \mathrm{m}^{-2} \mathrm{yr}^{-1}\right)$. On the basis of the assumption that, in Revellata Bay, C. balearica has its optimum growth between depths of 1 and $9 \mathrm{~m}$ (Clarisse 1984), the yearly production along the $9 \mathrm{~km}$ long shoreline is estimated to be about $10 \mathrm{t}$ of

\section{leads to branch loss.}

Fig. 6. Cystoseira balearica. Mean no. of branches plant ${ }^{-1}$ over time (black bar: 'old' branches; open bar: 'new' branches). No. above bar $=$ total length $(\mathrm{m})$ of branches plant $^{-1}$

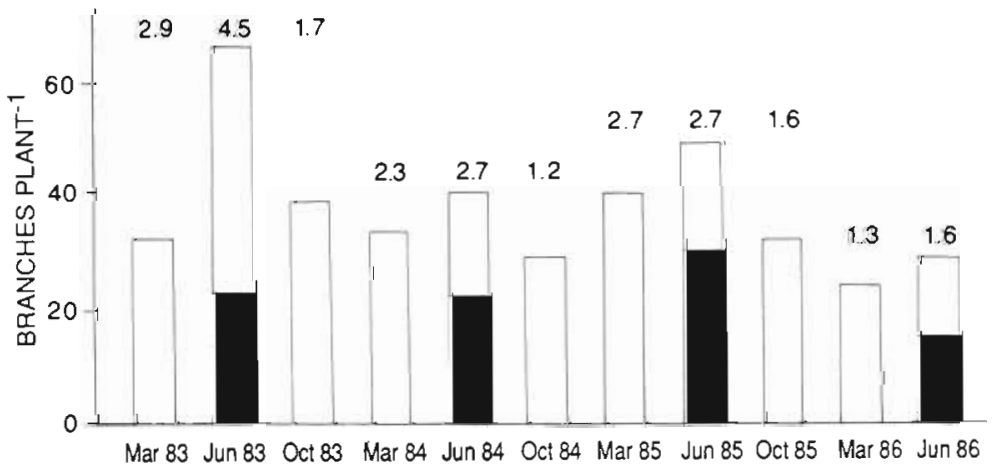


dry biomass $(=3.7 \mathrm{t} \mathrm{C})$. The dramatic regression of the Cystoseira belt observed since 1987 may thus have important consequences for this Mediterranean ecosystem.

\section{LITERATURE CITED}

Aguilar-Rosas, R., Machado Galindo, A. (1990). Ecological aspects of Sargassum muticum (Fucales, Phaeophyta) in Baja California, Mexico: reproductive phenology and epiphytes. Hydrobiologia 204/205: 185-190

Atkinson, M. J., Smith, S. V. (1983). C:N:P ratios of benthic marine plants. Limnol. Oceanogr. 28: 568-574

Bavaru, A. (1972). Quantitative evaluation of the Cystoseira populations of the Romanian shore of the Black Sea. Stud. Cercet. Biol., Ser. Bot. 24: 95-101

Bay, D. (1984). A field study of the growth dynamics and productivity of Posidonia oceanica (L.) Delile in Calvi bay, Corsica. Aquat. Bot. 20:43-64

Boudouresque, C. F. (1969). Qualitative and quantitative study of an algal population of Cystoseira mediterranea in the Banyuls-sur-Mer region (Département des Pyrénées Occidentales). Vie \& Milieu, Ser. B, Oceanogr. 20:437-452

Clarisse, S. (1984). Apport de différentes techniques cartographiques à la connaissance de l'autoécologie de Cystoseira balearica Sauvageau, macroalgue marine dominante dans la région de Calvi (Corse). Lejeunia 113: 1-24

Dauby, P. (1989). The stable carbon isotope ratios in benthic food webs of the Gulf of Calvi, Corsica. Contin. Shelf Res. 9: $181-195$

Ercegovic, A. (1952). Sur les Cystoseira adriatiques, leur morphologie, écologie et évolution. Fauna Flora, Adriatica 2: $1-112$

Firsov, Y. K., Khailov, K. M. (1979). Morphophysiological analysis of the hierarchical structure of Cystoseira barbata thalli. Bot. Mar. 22: 333-345

Frankignoulle, $\mathrm{M}$. (1986). Le système $\mathrm{CO}_{2}$ en milieu marın: activité biologique, interactions air-mer, caractérisation des masses d'eau dans la couche de surface. Thèse de doctorat, University of Liège

This article was submitted to the editor
Frantzis, A., Berthon, J.-F., Maggiore, F. (1988). Relations trophiques entre les oursins Arbacia lixula et Paracentrotus lividus (Echinoidea regularia) et le phytobenthos infralittoral superficiel dans la baie de PortCros (Var, France). Sci. Rep. Port-Cros natl Park, Fr. 14 $81-140$

Gomez Garreta, A., Ribera Siguan, M. A., Seoane Camba, J A. (1982). Phenological study of various species of the genus Cystoseira in Majorca. Collect. Bot. (Barcelona) 13 $841-856$

Gunnill, F. C. (1986). Demography of Cystoserra osmundacea and Halidrys dioica (Phaeophyta, Cystoseiraceae) at La Jolla, California, U.S.A. Bot. Mar. 29: 137-146

Hoffmann, L., Clarisse, S., Detienne, X., Goffart, A., Renard R., Demoulin, V. (1988). Evolution of the populations of Cystoseira balearica (Phaeophyceae) and epiphytic Bangiophyceae in the Bay of Calvi (Corsica) in the last eight years. Bull. Soc. R. Liège 4/5: 263-273

Khailov, K. M. (1978). Changes in the mass, length and metabolism of simple and composite thalli of marine macrophytes in their ontogenic series. Bot. Mar, 21: 313-321

Khailov, K. M. (1979). Ontogenic trends in morphologic parameters of Cystoseira harbata thalli. Bot. Mar. 22 $299-311$

Knoepffler-Peguy, M. (1973). Croissance et développement de Cystoseira (Phaeophyceae - Fucales) méditerranéens Helgoländer wiss. Meeresunters. 24: 476-489

Lejeune, P. (1985). Le comportement social des Labridés méditerranéens. Cah. Ethol appl. 5: 1-208

Nizamuddin, M. (1970). Phytogeography of the Fucales and their seasonal growth. Bot. Mar. 13: 131-139

Norton, T A. (1977). The growth and development of Sargâssum muticum (Yendo) Fensholt. J. exp mar. Biol. Ecol. 26: $41-53$

Sauvageau, C. (1912). A propos des Cystoseira de Banyuls et de Guethary. Bull. Stn biol. Arcachon 14: 133-556

Schiel, D. R. (1985a). A short-term demographic study of Cystoseira osmundacea (Fucales: Cystoseiraceae) in Central California. J. Phycol. 21:99-106

Schiel, D. R. (1985b). The growth, survival and reproduction of two species of marine algae at different densities in natural stands. J. Ecol. 73: 199-217

Manuscript first received: September 9, 1991

Revised version accepted: January 13, 1992 